\title{
The significance of pan-immune inflammation value and systemic immune inflammation Index in colorectal cancer screening
}

\section{Kolorektal kanser taramasında panimmün inflamasyon değerinin ve sistemik immün-inflamasyon indeksinin önemi olsun}

\author{
Sanem KAYHAN ${ }^{1 *}$ O Ozlem AYDIN ISAK²
}

'University of Health Sciences, Diskapi Yildirim Beyazit Training and Research Hospital, Department of Internal Medicine, Ankara/TURKEY 2University of Health Sciences, Diskapi Yildirim Beyazit Training and Research Hospital Department of Oncology Medical, Ankara/TURKEY

\begin{abstract}
Aim: It has been known for a long time that systemic inflammation is an important risk factor in cancer development. Colorectal cancer (CRC) is one of the most common causes of cancer-related morbidity and mortality in the world. In this study, we aimed to compare the inflammatory parameters tested in CRC patients at the time of diagnosis such as systemic immune-inflammation index (SII) and pan-immune inflammation value (PIV) with those of the healthy control group.
\end{abstract}

Materials and Methods: The data of 162 patients diagnosed with CRC in the internal medicine clinic between 20122016 were analysed retrospectively and a total of 139 patients who met the inclusion criteria were included in the study. Hemogram values, histopathology and tumour stage according to TNM classification of all patients at the time of diagnosis were recorded. The patients' neutrophil-lymphocyte ratio (NLR), platelet-lymphocyte ratio (PLR), lymphocytemonocyte ratio (LMR), SII and PIV were calculated using hemogram parameters such as neutrophils, monocytes, platelets and lymphocytes.

Results: A total of 139 CRC patients and 139 healthy control subjects with similar age and sex distribution were included in the study. The mean age of all subjects included in the study was $61.7 \pm 11.8$ years, and 170 subjects (61.2\%) were male. In the CRC group, SII, PIV, NLR, and PLR levels were significantly higher, and LMR level was significantly lower than the control group $(p<0.001, p<0.001, p<0.001, p<0.001, p=0.001$, respectively). When the CRC group was divided according to the disease stage, it was found that SII and PIV levels of all stages were significantly higher than the control group ( $p=$ 0.029, $p<0.001, p=0.001, p=0.002$ for SII, $p=0.034, p<0.001, p=0.002, p=0.014$ for PIV).

Conclusion: In addition to colonoscopy screening in patients with CRC, whose early diagnosis is very important, SII and PIV values that do not require an additional cost and can be measured in routine hemogram tests can also be taken into consideration.

Keywords: Colorectal cancer; systemic immune-inflammation index; pan-immune inflammation value

Corresponding author*: Sanem Kayhan, University of Health Sciences, Diskapi Yildirim Beyazit Training and Research Hospital, Department of Internal Medicine, Ankara/ TURKEY

E-mail: drkayhansanem@yahoo.com

ORCID: 0000-0001-7736-2681

Recevied:20.08.2021 accepted: 04.09.2021

Doi: $10.18663 / \mathrm{tjcl} .985559$ 


\section{öz}

Amaç: Sistemik inflamasyonun kanser gelişiminde önemli bir risk faktörü olduğu uzun zamandır bilinmektedir. Kolorektal kanser (CRC) de dünyada kanser ilişkili morbidite ve mortalitenin en sık nedenlerinden biridir. Bu çalışmada CRC'li hastalarda tanı anından bakılan sistemik immün-inflamasyon indeksi (SII) ve panimmun inflamasyon değeri (PIV) gibi inflamatuar parametrelerin sağlıklı kontrol grubu ile karşılaştırmayı amaçladık.

Gereç ve Yöntemler: 2012-2016 yılları arasında dahiliye kliniğinde CRC tanısı alan 162 hastanın verileri retrospektif olarak incelendi ve dahil edilme kriterlerini sağlayan toplam 139 hasta çalışmaya dahil edildi. Tüm hastaların tanı anında bakılan hemogram değerleri, histopatolojisi ve TNM sınıflamasına göre tümör evreleri kaydedildi. Hastaların nötrofil-lenfosit oranı (NLR), platelet-lenfosit oranı (PLR), lenfosit-monosit oranı (LMR), SIl ve PIV, nötrofiller, monositler, trombositler ve lenfositler gibi hemogram parametreleri kullanılarak hesaplandı.

Bulgular: Çalışmaya 139 CRC'li hasta ile yaş ve cinsiyet dağılımı benzer olan 139 sağlıklı kontrol grubu dahil edildi. Çalışmaya dahil edilen tüm vakaların yaş ortalaması $61.7 \pm 11.8$ olup 170'i erkek (\%61.2) idi. CRC grubunda SII, PIV, NLR ve PLR düzeyleri kontrol grubuna göre anlamlı yüksek, LMR düzeyi anlamlı düşüktü ( sırası ile $p<0.001 p<0.001 p<0.001$ $p<0.001 p=0.001$ ). CRC grubu hastalık evresine göre ayrıldığında tüm evrelerin kontrol grubuna göre SII ve PIV düzeyleri anlamlı yüksekti (SII için $p=0.029 p<0.001 p=0.001 p=0.002$ PIV için $p=0.034 p<0.001 p=0.002 p=0.014$ )

Sonuç: Erken tanısı büyük önem taşıyan CRC'li hastalarda kolonoskopik taramanın yanında, ek bir maliyet gerektirmeyen, rutin hemogram testi ile ölçülebilen SII ve PIV değerleri de dikkate alınabilir.

Anahtar kelimeler: Kolorektal kanser; sistemik immün-inflamasyon indeksi; panimmun inflamasyon değeri

\section{Introduction}

Colorectal cancer (CRC) is one of the most common causes of cancer-related morbidity and mortality around the world [1]. In our country, CRC is ranked fourth among malignant tumors that cause death [2]. Early diagnosis of $C R C$ reduces cancer-related mortality and increases survival. While 5-year survival rate is approximately $90 \%$ with early diagnosis, this rate decreases to $13 \%$ if the diagnosis is delayed [3]. For CRC screening, fecal occult blood test, colonoscopy, or radiological procedures are carried out. However, there are no widely accepted blood tests for CRC screening [4].

It has long been known that systemic inflammation is an important risk factor in cancer development. It has been shown that chronic inflammation suppresses immune activity and promote tumour development [5]. Mediators released to the environment as a result of inflammation cause cellular DNA damage, inhibition of apoptosis, and development of angiogenesis, and this leads to the growth and progression of the tumour cells and metastasis [6]. Previous evidence has indicated that chronic inflammation played an extensive role in CRC development and progression [6]. It has previously been reported that systemic inflammatory markers are an important independent predictive marker in the prognosis of CRC. Several studies have focused on peripheral inflammatory cells, and calculated the ratios as parameters reflecting the immune response status in cancer patients [8]. Among these parameters are the parameters such as neutrophil-lymphocyte ratio (NLR), platelet-lymphocyte ratio (PLR), and lymphocyte/ monocyte ratio (LMR).

Recently, systemic immune-inflammation index (SII) and pan-immune inflammation value (PIV) have emerged as the new inflammatory markers based on platelets, monocytes, neutrophils, and lymphocytes in complete blood count [9] As a novel prognostic parameter, SII and PIV can be easily calculated from routine complete blood count tests and reflects the overall status of the immune systems of cancer patients [10] Many studies have investigated the prognostic role of SII and PIV in CRC patients, but their roles in cancer development and progression are still discussed [11,12].

Inclusion of effective biomarkers in diagnostic strategies can improve the outcome significantly for patients with CRC. In this study, we aimed to compare the SII and PIV values in CRC patients at the time of diagnosis with the healthy control group.

\section{Materials and Methods}

This study was designed as a retrospective, cross-sectional study. Ethical approval for the study was obtained from The Ethics Committee of our institute, according the principles of the Declaration of Helsinki. Informed written consents of all patients were obtained before inclusion. 
The data of 162 patients diagnosed with CRC in the internal medicineclinic between 2012-2016 wereanalysed retrospectively. Hemogram values, histopathology and tumour stage according to TNM (tumor-lymph nodes-metastasis) classification of all patients at the time of diagnosis were recorded.

Patients assigned with histopathological diagnosis of CRC, whose treatment was not yet started and/or operated on, were included in the study. Patients previously received anti-tumour treatment such as chemotherapy or radiotherapy, patients diagnosed with another malignancy, with kidney failure or cirrhosis, patients with known haematological, autoimmune, or chronic inflammatory disease, patients who developed an acute infection during hospitalization, or patients receiving treatments such as steroid, anti-inflammatory, and immunosuppressive treatments that may cause changes in inflammatory markers were excluded from the study. The data of a total of 139 patients who met the inclusion criteria were analyzed statistically.

The patients' NLR, PLR, LMR, SII, and PIV were calculated using blood cell counts based on systemic inflammation markers such as neutrophils, monocytes, platelets and lymphocytes. SII was calculated by multiplying NLR and platelet count, PIV was calculated by multiplying SII and monocyte count.

\section{Statistical Analysis}

Statistical analysis was performed using SPSS Version 25. Normality distribution analysis of the data was performed by using Kolmogorov-Smirnov and Shapiro-Wilk tests. Descriptive analyses were expressed using means and standard deviations for normally distributed variables whereas medians and min-max were used for non-normally distributed variables. The differences between independent groups in terms of numerical variables were examined using the student's t- test to compare means. Non-normally distributed data were expressed as the median values and compared using the Kruskal-Wallis and Mann-Whitney U-test. Chi-square (x2) test was used to analyze ccategorical variables. Pearson's tests were used to test correlations and the degree of associations among variables. A P-value of $<0.05$ was considered statistically significant.

\section{Results}

Of 278 subjects included in the study, 139 were assigned to the CRC and 139 to the healthy control group. Clinical and laboratory characteristics of the colorectal cancer group are given in Table 1. The mean age of all subjects included in the study was $61.7 \pm 11.8$ years, and 170 of the subjects were male (61.2\%) and 108 were female (38.8\%). CRC and healthy control

groups were similar in terms of their age and sex distribution $(p=0.8, p=0.99$, respectively), and the demographic and laboratory data of the groups are shown in Table 2. In colorectal cancer group, SII, PIV, NLR, and PLR levels were significantly higher, and LMR level was significantly lower than the control group $(p<0.001, p<0.001, p<0.001, p<0.001$, $p=0.001$, respectively) (Table 2 ). When the colorectal cancer group was divided according to the disease stage, it was found that all stages had significantly higher SII and PIV values than the control group $(p=0.029, p<0.001, p=0.001, p=0.002$ for SII, $p=0.034, p<0.001, p=0.002 p=0.014$ for PIV) (Table 3).

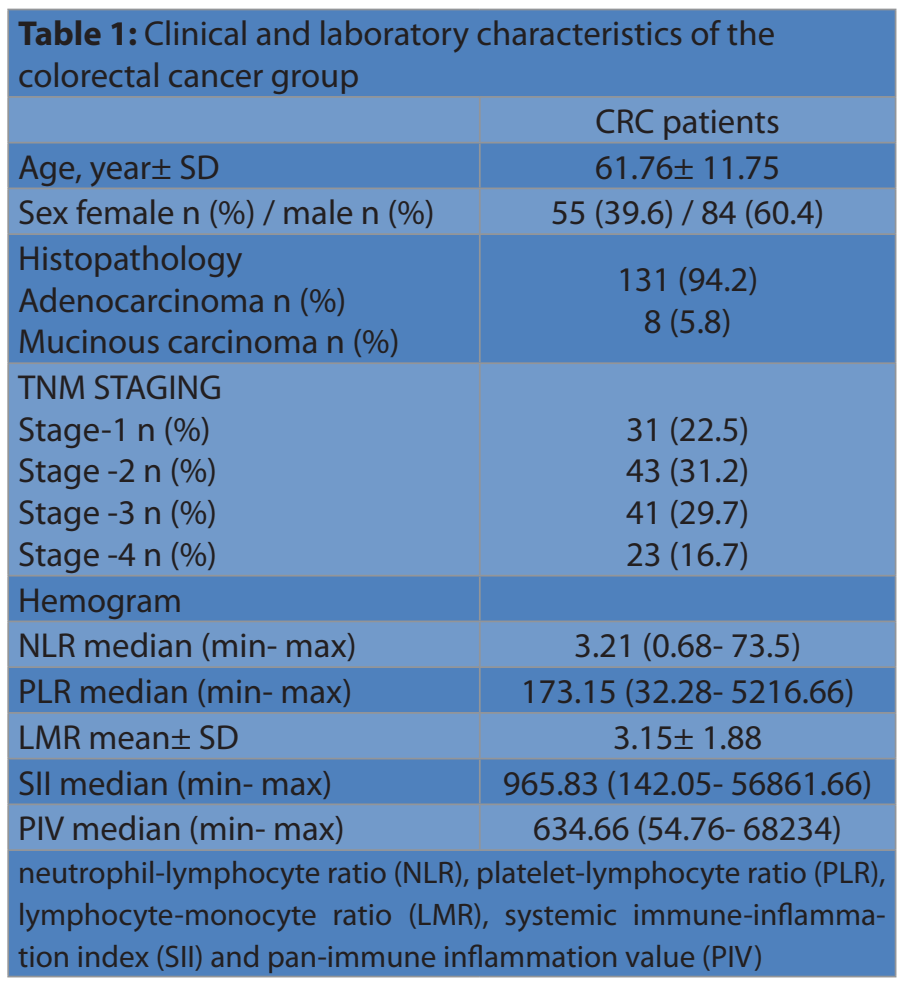

\begin{tabular}{|c|c|c|c|}
\hline & CRC & HEALTHY CONTROL & $P$ \\
\hline Age mean \pm SD & $61.76 \pm 11.75$ & $61 \pm 11.8$ & 0.99 \\
\hline $\begin{array}{l}\text { Sex female } n \\
(\%) \text { / male } n(\%)\end{array}$ & $\begin{array}{l}55(39.6) / \\
84(60.4)\end{array}$ & $\begin{array}{l}53(38.1) / \\
86(61.9)\end{array}$ & 0.8 \\
\hline $\begin{array}{l}\text { SIl median } \\
\text { (min- max) }\end{array}$ & $\begin{array}{c}965.83(142.05- \\
56861.66)\end{array}$ & $\begin{array}{l}581.45(40.85- \\
4826.25)\end{array}$ & $<0.001$ \\
\hline $\begin{array}{l}\text { PIV median } \\
\text { (min- } \max )\end{array}$ & $\begin{array}{c}634.66(54.766- \\
68234)\end{array}$ & $\begin{array}{l}309(16.34- \\
5308.87)\end{array}$ & $<0.001$ \\
\hline $\begin{array}{l}\text { NLR median } \\
\text { (min- max) }\end{array}$ & $\begin{array}{l}3.21(0.68- \\
73.5)\end{array}$ & $2.3(0.69-17.88)$ & $<0.001$ \\
\hline $\begin{array}{l}\text { PLR median } \\
\text { (min- max) }\end{array}$ & $\begin{array}{c}173.15(32.28- \\
5216.66)\end{array}$ & $\begin{array}{l}125.18(27.14- \\
405.71)\end{array}$ & $<0.001$ \\
\hline LMR mean \pm SD & $3.15 \pm 1.88$ & $3.86 \pm 1.73$ & 0.001 \\
\hline
\end{tabular}




\begin{tabular}{|c|c|c|c|c|}
\hline & SII & $\mathrm{P}^{*}$ & PIV & $\mathrm{P}^{* *}$ \\
\hline Control & $\begin{array}{c}581.45(40.85- \\
4826.25)\end{array}$ & & $\begin{array}{c}309(16.34- \\
5308.87)\end{array}$ & \\
\hline Stage-1 & $\begin{array}{c}906.6(182.55- \\
14259)\end{array}$ & 0.029 & $\begin{array}{c}400.4(54.76- \\
19660.1)\end{array}$ & 0.034 \\
\hline Stage-2 & $\begin{array}{c}1206.02(298.51- \\
3991.77)\end{array}$ & $<0.001$ & $\begin{array}{l}738486.48 \\
(144300- \\
3193422.22)\end{array}$ & $<0.001$ \\
\hline Stage-3 & $\begin{array}{c}961(142.05- \\
56861.66)\end{array}$ & 0.001 & $\begin{array}{c}\text { 676.08(7.12- } \\
68234)\end{array}$ & 0.002 \\
\hline Stage-4 & $\begin{array}{c}953.33(387.33- \\
7511)\end{array}$ & 0.002 & $\begin{array}{c}480.11(78.75- \\
6759.9)\end{array}$ & 0.014 \\
\hline \multicolumn{5}{|c|}{$\begin{array}{l}\text { neutrophil-lymphocyte ratio (NLR), platelet-lymphocyte ratio (PLR), } \\
\text { lymphocyte-monocyte ratio (LMR), systemic immune-inflamma- } \\
\text { tion index (SII) and pan-immune inflammation value (PIV) }\end{array}$} \\
\hline
\end{tabular}

\section{Discussion}

In our study, SII and PIV values in new diagnosed CRC patients were significantly higher than the healthy control group.

Inflammation plays a determining role in different stages of tumour development such as initiation, progression, invasion, and metastasis. Systemic inflammation, characterized by the secretion of cytokines and chemokines, leads to cellular DNA damage, inhibition of apoptosis and development of angiogenesis, and this causes the growth and progression of tumour cells and metastases $[6,13]$. Previous evidence has shown that chronic inflammation plays an extensive role in the development and progression of CRC [7].

Systemic inflammation against tumours can be demonstrated by the presence of certain inflammatory markers. The relationship between inflammatory indices such as SII and PIV and tumour development or grade has not been completely understood. Neutrophils and lymphocytes are the important components of inflammatory response in many cancer types. It was found that tumour-associated neutrophils play an important role in cancer biology [14]. Suppression of lymphocyte function by activated neutrophils and consequent lymphopenia leads to a lower anti-tumour activity. These cells were shown to promote tumour growth and suppress antitumour immune response [15]. Moreover, it has been known that thrombocytes increase the invasive capacity of circulating tumour cells, induce epithelial-mesenchymal transition, and promote metastasis [16]. Again, peripheral monocytes are the source of myeloid-derived suppressor cells that ensure cancer progression [17]. SII and PIV indices that evaluate the combined effect of these inflammatory cells (neutrophil, lymphocyte, platelet, and monocyte) enable the combined evaluation of anti-tumour systemic inflammation

In a meta-analysis, Yang et al. investigated 7196 patients from 22 studies, and demonstrated that SII has prognostic significance both for progress-free survival and overall survival in many types of cancer including oesophageal carcinoma, gastric, prostate, renal and biliary tract cancers [18]. Again, in another meta-analysis, it was shown that an elevated SII is associated with clinical factors, implying higher malignancy of the disease, and high SIl levels predicted poor prognosis in CRC [11]. In another inflammation-based study; prognostic effect of PIV was demonstrated in patients with metastatic CRC [12]. In our study, SII and PIV values were significantly higher in new diagnosed CRC patients than the healthy control group. Our results demonstrate that there is a significant relationship between inflammatory markers and cancer. This relationship was shown not by the scorings based on two types of inflammatory cells such as NRL or PRL but with scorings that reflect the balance between the host immune system and inflammation better such as SII and PIV that include three-four types of inflammatory cells.

In our study, although the presence of a cancer-related systemic inflammatory response in CRC was demonstrated, no relationship could be detected between cancer staging and these inflammatory indices. In fact, it has been shown that neutrophils, monocytes, and platelets increase cancer cell invasion and metastasis $[13,19,20]$. Lymphocytes are known to play an important role in defence against tumour by inducing cytotoxic cell death and inhibiting tumour cell proliferation and migration [21]. Cancer progression and metastasis is believed to increase with systemic inflammation [22]. In light of these data, we expected to see an increase in SII and PIV values in advanced stages in CRC patients. However, in this study, although the role of SII and PIV in cancer development was demonstrated, this could not be associated with tumor stages. This may be due to the fact that the degree of immune response of each patient to the cancer cell is different. We believe that larger and more comprehensive studies are required to find the reason for this.

Our study had some limitations. These were the study's retrospective design, which limited the number of patients. Therefore, larger and prospective studies are required to confirm these preliminary results.

\section{Conclusion}

This study demonstrated the importance of inflammation in CRC development, using potent immunological parameters such as SII and PIV that reflect combined systemic inflammatory 
response. These new biomarkers of inflammation can represent a significant step toward understanding the biology of CRC. In addition to colonoscopy screening in patients with CRC, whose early diagnosis is very important, SII and PIV values that do not require an additional cost and can be measured in routine hemogram tests can also be taken into consideration.

\section{Declaration of conflict of interest}

The authors received no financial support for the research and/or authorship of this article. There is no conflict of interest

\section{References}

1. Bray F, Ferlay J, Soerjomataram I, et al. Global cancer statistics 2018: GLOBOCAN estimates of incidence and mortality worldwide for 36 cancers in 185 countries. CA: a cancer journal for clinicians. 2018; 68: 394-424.

2. Gültekin $M$, Boztaş G. Türkiye kanser istatistikleri. Sağlık Bakanlığı, Türkiye Halk Sağlığı Kurumu. 2014; 43: 12-32.

3. Mattiuzzi C, Sanchis-Gomar F, Lippi G. Concise update on colorectal cancer epidemiology. Annals of translational medicine. 2019; 7 :609.

4. Ilgaz $A E$, Gözüm S. Determination of Colorectal Cancer Risk Levels, Colorectal Cancer Screening Rates, and Factors Affecting Screening Participation of Individuals Working in Agriculture in Turkey. Cancer nursing. 2018; 41: 46-54.

5. Hanahan D, Weinberg RA. Hallmarks of cancer: the next generation. Cell. 2011; 144: 646-74.

6. Kim DK, Oh SY, Kwon HC, et al. Clinical significances of preoperative serum interleukin-6 and C-reactive protein level in operable gastric cancer. BMC cancer. 2009; 9: 155.

7. Lasry A, Zinger A, Ben-Neriah Y. Inflammatory networks underlying colorectal cancer. Nature immunology. 2016; 17: 230-40.

8. Maeda K, Shibutani M, Otani H, Nagahara H, Ikeya T, Iseki Y, et al. Inflammation-based factors and prognosis in patients with colorectal cancer. World journal of gastrointestinal oncology. 2015; 7: 111-7.

9. Hong X, Cui B, Wang M, et al. Systemic Immune-inflammation Index, Based on Platelet Counts and Neutrophil-Lymphocyte Ratio, Is Useful for Predicting Prognosis in Small Cell Lung Cancer. The Tohoku journal of experimental medicine. 2015; 236: 297-304.

10. Jomrich G, Gruber ES, Winkler D, et al. Systemic ImmuneInflammation Index (SII) Predicts Poor Survival in Pancreatic Cancer Patients Undergoing Resection. Journal of gastrointestinal surgery : official journal of the Society for Surgery of the Alimentary Tract. 2020; 24: 610-8.
11. Dong M, Shi Y, Yang J, et al. Prognostic and clinicopathological significance of systemic immune-inflammation index in colorectal cancer: a meta-analysis. Therapeutic advances in medical oncology. 2020; 12: 1758835920937425.

12. Fucà G, Guarini V, Antoniotti C, et al. The Pan-ImmuneInflammation Value is a new prognostic biomarker in metastatic colorectal cancer: results from a pooled-analysis of the Valentino and TRIBE first-line trials. British journal of cancer. 2020; 123: 403-9.

13. Mantovani A, Allavena P, Sica A, et al. Cancer-related inflammation. Nature. 2008; 454: 436-44.

14. Fridlender ZG, Albelda SM. Tumor-associated neutrophils: friend or foe? Carcinogenesis. 2012; 33: 949-55.

15. Gooden MJ, de Bock GH, Leffers N, et al . The prognostic influence of tumour-infiltrating lymphocytes in cancer: a systematic review with meta-analysis. British journal of cancer. 2011; 105: 93-103.

16. Labelle M, Begum S, Hynes RO. Direct signaling between platelets and cancer cells induces an epithelial-mesenchymal-like transition and promotes metastasis. Cancer cell. 2011; 20: 576-90.

17. Karakasheva TA, Dominguez GA, Hashimoto A, et al. CD38+ M-MDSC expansion characterizes a subset of advanced colorectal cancer patients. JCl insight. 2018; 3.

18. Yang R, Chang Q, Meng X, Gao N, et al. Prognostic value of Systemic immune-inflammation index in cancer: A metaanalysis. Journal of Cancer. 2018; 9: 3295-302.

19. Schumacher D, Strilic B, Sivaraj KK, et al. Platelet-derived nucleotides promote tumor-cell transendothelial migration and metastasis via P2Y2 receptor. Cancer cell. 2013; 24: 130-7.

20. Cools-Lartigue J, Spicer J, McDonald B, et al. Neutrophil extracellular traps sequester circulating tumor cells and promote metastasis. J Clin Invest. 2013; 123: 3446-58.

21. De Giorgi U, Mego M, Scarpi E, et al. Relationship between lymphocytopenia and circulating tumor cells as prognostic factors for overall survival in metastatic breast cancer. Clinical breast cancer. 2012; 12: 264-9.

22. Abe T, Amano H, Kobayashi T, et al. Preoperative neutrophil-tolymphocyte ratio as a prognosticator in early stage pancreatic ductal adenocarcinoma. European journal of surgical oncology : the journal of the European Society of Surgical Oncology and the British Association of Surgical Oncology. 2018; 44: 1573-9. 